\title{
The Facebook-in-action: Challenging, Harnessing and Enhancing Students Class Assignments and Projects
}

\author{
Adam Mohd Saifudin ${ }^{1, *}$, Aizan Yacob $^{2}$, Rohaizah Saad ${ }^{1}$ \\ ${ }^{1}$ College of Business, Northern University of Malaysia, Malaysia \\ ${ }^{2}$ College of Arts and Sciences, Northern University of Malaysia, Malaysia
}

Copyright $\mathrm{O} 2016$ by authors, all rights reserved. Authors agree that this article remains permanently open access under the terms of the Creative Commons Attribution License 4.0 International License

\begin{abstract}
Issues of universities students harnessing and capitalizing the usage of Facebook for their own learning capabilities and effective thinking is always the focus of education scholars, in assessing the quality class assignments and projects produced by them. Therefore, Facebook is now becoming unbearable influence since the internet activation in the past few years, almost totally interconnected the information sharing and needs among those students. In this action research, the researchers explore the influence and the active usage of Facebook whether this social media networking is confirmed challenging, enhancing and harnessing the learning capabilities and effective thinking among the university students. Thus they could produce quality class assignments and projects under the supervision of their lecturer concerned.
\end{abstract}

Keywords Action Research, Facebook, Social Media Networking, Universities, Harnessing, Capitalizing and Learning

\section{Introduction}

Facebook (FB) is now becoming an unbearable influence among the students in this social media networking. It challenges the education scholars to study of students' commitment in class assignments and projects. With over 800 million active FB users around the world with $50 \%$ visit the site daily [1], it has changed our daily lives, ways of communication and interacting with the social media networking. At this stage, FB is the most visited website in the world [2] and is the most widely used social media networking platform, with over 1 billion monthly users [3]. For Malaysia, the influence of FB usage could be highly described from the figures reported previously [4]. According to the report in 2012, Malaysia has 34 million mobile subscribers and 17.5 million internet users of which 87.9 percent of the Internet users are accessed to FB. The report added that by July 2013, there are 13.3 million users in this country. The statistics stated that FB users aged between 18 to 24 years are the highest users, contributing 34.5 percent as users, followed by aged between 25 to 34 years ( 29.5 percent) and 13 to 17 years (16.3 percent). Thus this prove to be the correct relationships why students in the universities and other higher learning institutes are serious users of FB as they are mostly from the ripe aged of 18 to 24 years. However, even with this huge rise of FB users in Malaysia as compared few years back, the report stated that it is still at infant stage.

\section{Literature Review}

Previous researchers [5] defined social network sites (including FB) as web-based services that allowed individuals to (1) construct a public or semi-public profile within a bounded system, (2) articulate a list of other users with whom they share a connection, and (3) view and traverse their list of connections and those made by others within the system. FB operates by connecting users with their friends, family, and acquaintances. Users create detailed profiles describing their activities, interests, and values, and then articulate 'friendships' with other users in the system. Communication between friends are then publicly posted and archived onto the profile [5]. In a previous publication [6], there were four studies pertaining to the FB usefulness in teaching. The author cited the first study [7] explored the utilization of FB features to teach information literary concepts in library research and technology. She related that FB terms for her subject's concepts made the latter easily understood. The second study [8] highlighted that FB facilitates faculty-students and student-student contact by 'effectively lowering barriers to communication. When properly understood and used as intended, FB could be an excellent virtual medium for building and maintaining real world social connections within a class'. The third study [9] showed that students would discuss chemical concepts outside regular class time in FB more frequently than they did in WebCT, with the data 
suggested FB as an alternate mode of communication. The results showed that FB is a good medium for communication in the sense those students would use it. Lastly, the fourth study [10] revealed that a teacher effectively used FB to support classroom discussions in physics' class. It was opined that the benefits to learners of the practice include increased collaborative' learning opportunities, improved learner engagement, enhanced student-faculty contact, encouragement of active learning, and enabling a mechanism for timely feedback on assessed material. It is not surprised that some researchers critically addressed FB research are seriously related to those graduates who are applying for jobs [11]. According to them, recruiters viewed applicants' profiles and made judgments concerning applicants' suitability and their knowledge, skills, abilities, and other characteristics. It then correlated recruiter ratings with applicants' subsequent job performance and turnover which the results help to address two critical gaps that exist in the knowledge of the social media for staffing phenomenon. Firstly, according to previous research publications [11][12][13], there is virtually no research concerning whether or how assessments of social media information relate to criteria organizations attempt to affect through their staffing procedures. The only study could be found is to review FB profiles of undergraduate students and rate students' personality and hire ability [14]. Secondly, there are no published data on whether social media assessments are similar or different across subgroups of applicants. This is unfortunate because subgroup differences can lead to adverse impact [15], which can negatively affect organizational diversity and jeopardize the legal defensibility of selection decisions [16]. The research gap is address by examining whether FB based ratings differ by gender and ethnicity [11]. Previous scholars relatively studied about learning capability and effective thinking is related to the creativity of the mind and FB proved to be part of the major answers. In the book 'The Lateral Thinking for Management' [17], the author mentioned that 'it is certainly possible to be creative or to use lateral thinking without having any knowledge of the basic information processes of the mind'. FB has just proven the right instrument and tools for the mind to work out the creativity attractively.

\section{Problem Statements}

The influence of FB for teaching and learning concept and practice is very practical and effective indeed. However it must be systematically used and practice for the advantage of students applications in producing quality assignments and projects, thus enhancing them to have the learning capabilities and effective thinking. This could be the main issue if it is not being addressed and focus about. FB needs some form of control over the over-used of FB from being spilled into over-obsessiveness in using it [18] [19].

\section{Research Objectives}

To study to what extend Facebook enhance students' learning capabilities in preparing the class assignments and projects.

To study to what extend Facebook improve students' effective thinking in producing quality class assignments and projects.

\section{Methodology}

The researcher used the cycle of action research model [20] as in Figure 1. In this model, the cycle converge towards better understanding and improved action implementation; and are based in evaluative practice that alters in between the action and critical reflective. The action research [20] is seen as an experimental learning to change the goal of which is continually refine the methods, data and interpretation in the light of understanding developed in the earlier cycles. Previous researcher [21] mentioned there was a 'side spiral' so that the researchers might find something relevant and of interest that should also be investigated alongside, and sometimes instead of the 'main' question [22]. As it was defined previously [23], action research is an enquiry, undertaken with rigor and understanding so as to constantly refine practice. 


\section{0 'Leary's cycles of research.}

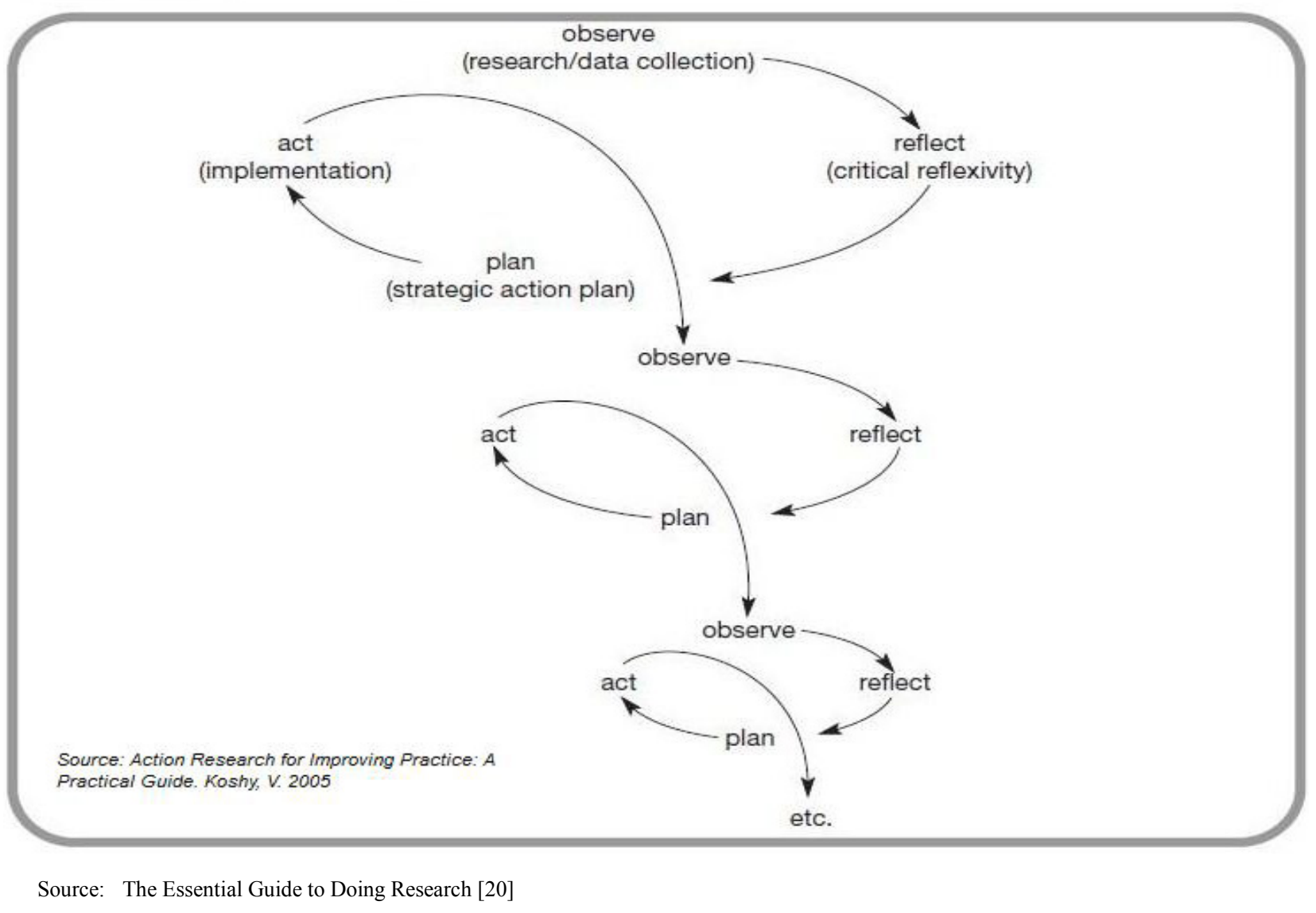

Figure 1. O'Leary Cycles Action Research

The researcher conducted the research by distributing the survey questionnaires, interviews with the students, observations, reflections and literatures. He used O'Leary's cycle model into three (3) cycles or stages for the action research with McNiff sequence to plan, act, observe and reflect. The First Cycle is to identify the problems about the FB usage before it is compulsory imposed on the students activities in producing their assignments and projects. This is followed by the Second Cycle as to examine the FB usage after the instructions to changes in using the FB is done on the students' activities in producing their class assignments and projects. Finally, the Third Cycle is to examine their answers to the research questions. The research is conducted in the researcher's lecture class of BJMP 3053: Operations Strategy in the Production and Operations Management Program, School of Technology Management and Logistics, College of Business, University Utara Malaysia as the scope of the research. The class had 28 final semester students and divided into 10 groups with each group comprised of 2 to 3 students. Assignments and projects are given to each group and they need to prepare, produce and present in class of their given topics. Each group need to present in class every week according to their turn of presentations. The class presentation only allows 1 presentation a week. The first cycle comprised of 3 groups follow by second cycle ( 3 groups) and third group (4 groups) with a total of 10 weeks to complete all the three cycles.

\section{Data Sources and Collections}

The data is collected from 28 final semester students of the researcher's lecture class of BJMP 3053 Operations Strategy. Survey questionnaires forms are distributed to the students in three cycles. Each cycle represented the changes of the feedbacks from the students with improvements and ideas applied in the class. This is based from the researcher's plan, act, observe and reflect over the changes and improvements in establishing and enhancing their learning capabilities and effectiveness of thinking in producing quality class assignments and projects. In the First Cycle, the researcher plans, acts and observes to distribute the survey questionnaires to the 3 groups concerned after their respective class presentations and this is done in the next 3 weeks. They are assumed to have no knowledge about using the FB to enhance their preparation, producing and presenting their assignments and projects. The researcher reflects to identify their problems and how that $\mathrm{FB}$ 
influences their activities in preparing the class assignments and projects. In the Second Cycle, the researcher plans, acts and observes by giving some new instructions related to the use of FB for the students to prepare the assignments and projects. The new instructions are based from the answers given in the First Cycle questionnaires to ensure that the students have clear guidelines to eliminate any problems faced when communicating among the group members. The FB usage is then effectively accessible among the students and the lecturer concerned in producing their assignments and projects. Among the instructions and changes for the students to adhere in using the FB are all communications must through the FB between the students and lecturers or students and students. Instructions and guidelines are given to them to follow strictly. Deadline of the assignments and projects completions are clearly stated to be submitted to the lecturer concerned. The researcher reflects the information sharing and consultations in getting the works done as priority. He distributed the same set of survey questionnaires to the next 3 groups concerned in the next 3 weeks after each group presentation respectively to get the feedback before going into the Third Cycle. In the Third Cycle, the researcher plans, acts and observes to do some follow-up changes of the instructions (if required) for the students based on the answers given by the students in the questionnaires during the Second Cycle. He reflects the changes and what need to be done before the same set of survey questionnaires to be distributed to the final next 4 groups concerned in the next 4 weeks after each group presentation respectively. After all the Third Cycle completed, the researcher plans, acts and observes to quantify and qualify the data collected and do the reflections in the findings pertaining to the whole process of the answer to the research questions (refer to QN 11 and QN 12 in APPENDIX A). This would determine whether the FB has created students awareness, learning capabilities and effective thinking in producing quality class assignments and projects.

\section{Data Collections and Analysis}

The data (as in APPENDIX A) were collected and added from the questionnaires distributed to the students by weekly and completed on the week 10 from all the three cycles. Based on this data, 64 percent (18 students) was actively communicated using the FB and 100 percent (28 students) always actively using the FB. Even though 100 percent $(28$ students) agreed that they were using other communication instruments before the FB but they felt difficult to prepare and finish class assignments and projects, to prepare and communicate with friends and felt difficult to settle the problem in preparing the assignment and project, without the FB. This was supported with 100 percent (28 students) agreed that they felt easier with FB when preparing and communicating with friends and no problems in preparing the assignment and project. This reflected the seriousness of FB influence over their studies activities. 89 percent $(25$ students) agreed that the FB that they harnessed had created the learning capabilities in preparing the assignments and projects while 4 percent ( 1 student) did not agree with 7 percent ( 2 students) neither agreed nor not. 75 percent $(21$ students) of the students too agreed that the FB they harnessed has created the effectiveness to think in producing quality assignments and projects while 18 percent ( 5 student) did not agree with 7 percent ( 2 student) neither agreed nor not. This reflected the continuous ability of students to cultivate and culminate the learning capabilities and effective learning in preparing and producing the quality class assignment and projects.

\section{Findings Analysis}

The findings are analyzed through the 3 cycles as explained in the methodology as follows:

\subsection{First Cycle}

It was observed that the students were very much aware of the FB communication and how important it was in their works to prepare and complete the class assignments and projects. The researcher reflections pointed that the usage of FB already in their mind-sets and they acted as expert operators in utilizing the FB for their own advantage. Thus this makes the job for the teaching and learning much easier with the lecturer concerned too is to be part of their FB savvy. It was also found that the FB too is incapable to be academically savvy. The researcher observed that there were some elements of negative or problems over the use of FB for the academic purposes. The researcher reflected that some of the students are not so serious in utilizing FB for their needs to prepare the assignments and projects. In his opinion, they should be more opened in justifying the use of FB so that it could be to their own advantages during the studying period or preparation of their assignments or projects. This needs to be addressed seriously to them so that they are aware of utilizing the FB effectively. The researcher too found that the FB is also being described as fun but failed to create thinking students. This due to very minimal opened discussions or information sharing about their assignments and projects or related to their studies conducted in the FB. In fact the researcher did not find any good discussions that reflected their critical thinking or any subjects related to their studies. Researcher reflected that some mostly students treated FB for fun and not for studies. A serious plan needs to be done to ensure that FB should be used as education instruments effectively.

\subsection{Second Cycle}

Based on the observation, FB is treated as instrument to effective thinking and studying. Before the start of the Second Cycle, a clear directive was given to all students that they must communicate in FB with the creation of BJMP 
3053 Operations Strategy FB officially. They too need to prepare all the necessary materials for class assignments and projects to be uploaded in the FB. It was observed that there was some seriousness over these instructions that the students had to adhere in avoiding any negative perceptions by lecturer over their commitment. The writer reflected that if the FB activities for the students were organized seriously, the students too were taking the FB as important as their studies participations. Even though after the early Second Cycle plan and act was effectively implemented with the new changes instructed in the FB communications, the researcher observed that there were some students who perceived that the success of FB utilization was depending on the individual conditions. The writer reflection was that there were still some doubts over the use of FB as it concerned with vague assumption of individual perceptions and dependability. In this case, any person's dependability depending on the support instrument or mechanism of studying such as FB to make them a better learned person. This needs to be addressed effectively to them.

\subsection{Third Cycle}

The researcher did not make any plan and act to add more changes to new instructions for the FB usage. The researcher observed that majority of students agreed that FB had enhanced the learning capabilities in preparing the class assignments and project after the major changes and instruction during the Second Cycle. It is a positive reflection for their commitment. In the interviews with some of them, they agreed that FB had brought great changes in their studies life. The researcher observed that the students too agreed that FB had improved the effectiveness of students thinking in producing quality class assignments and projects tremendously. The writer reflected that with the initial guidelines in preparing the assignment and project, the students were slowly building their team works to produce quality works. They were also found to be very serious in finishing their works and everyone was contributing to produce the best class assignments and projects. Overall, the researcher observed that the students did communicate but nothing much were discussed over the questions or answers on how to ensure their assignments and projects could be best produced in quality. The researcher reflection over this issue was that the assignments and projects they produced were really good but that did not really reflect their actual cognitive strengths when debating into how it could be best produced in quality. Not many questions or issues being raised during such period of time in preparing their assignments and projects. Most probably instructions given to them were sufficed but the timing of completing the works was limited. However, this issue needs to be addressed so that they can properly plan their studies and be more active to discuss their works preparation in the FB seriously theoretical and practical.

\section{Conclusion, Contribution and Future Recommendation}

The researcher concluded that there are positive awareness of using FB in harnessing and enhancing the students' learning and thinking capabilities in preparing the class assignments and projects. It was also found that the students were more concerned over the timing being produced but the quality works of each of their members were progressing well even it was not being highlighted frequently. Thus the assignments and projects they produced were excellent but that did not really reflect their intelligent on critical thinking especially when voicing out their opinions or arguments in the FB. However, the researcher felt that FB did build close relationship between the students and lecturers which positively are easily building up the students' relationships at the initial to final stage of their studies. They capitalized the FB to enhance and created their own learning capability and effective thinking even this did not being highlighted prominently in the FB. Based on the evidenced of excellent works produced, it enhanced and created the quality works of the students in producing the quality class assignment and project. This research indeed contributed to the enhancement of knowledge and the exposure to the university students that FB indeed could commit them to be intelligent and build their critical thinking if being guided seriously. With the world is now focusing and relying on the internet information, FB and other social media networking are steadily influencing and impacting the students on how relevant and updated the knowledge information to make them a good scholar. For the future recommendation, research on the usage of FB among the university students should be continuously studied as an evidence of the students' progress not only in their learning and studies, but also in other field of studies that relate to teaching and learning. This could enhance the success of teaching and learning process application to create a better Students Centered Learning (SCL) at university level.

\section{Acknowledgements}

This paper is under scholarship of the university. 


\section{Appendix}

\section{Summary of Survey Results}

\begin{tabular}{|c|c|c|c|}
\hline QN \& Items: & & $\begin{array}{c}\text { No. of Students } \\
\text { (Frequency) }\end{array}$ & $\begin{array}{c}\text { Percentage } \\
(\%)\end{array}$ \\
\hline Q0: Gender & $\begin{array}{l}\text { Male } \\
\text { Female }\end{array}$ & $\begin{array}{l}12 \\
16\end{array}$ & $\begin{array}{l}43 \\
57\end{array}$ \\
\hline Q0: Aged & $\begin{array}{c}22 \text { years } \& \text { below } \\
23 \text { years } \\
24 \text { years } \\
25 \text { years \& above }\end{array}$ & $\begin{array}{c}1 \\
19 \\
7 \\
1\end{array}$ & $\begin{array}{l}3.5 \\
68 \\
25 \\
3.5\end{array}$ \\
\hline Q0: Nationality & $\begin{array}{c}\text { Malaysian } \\
\text { Others (Nigerian) }\end{array}$ & $\begin{array}{c}27 \\
1 \\
\end{array}$ & $\begin{array}{c}96 \\
4\end{array}$ \\
\hline Q1: Years registered with Facebook & $\begin{array}{c}3 \text { to } 4 \text { years } \\
5 \text { years \& above }\end{array}$ & $\begin{array}{l}11 \\
18\end{array}$ & $\begin{array}{l}39 \\
61\end{array}$ \\
\hline Q2: Years active in using the Facebook & $\begin{array}{c}0-1 \text { year } \\
1 \text { to } 2 \text { years } \\
3 \text { to } 4 \text { years } \\
5 \text { years \& above } \\
\end{array}$ & $\begin{array}{c}1 \\
2 \\
20 \\
5\end{array}$ & $\begin{array}{c}4 \\
7 \\
71 \\
18\end{array}$ \\
\hline Q3: Always communicate in the Facebook & $\begin{array}{l}\text { Yes } \\
\text { No }\end{array}$ & $\begin{array}{l}18 \\
10\end{array}$ & $\begin{array}{l}64 \\
36\end{array}$ \\
\hline Q4: Always active using the Facebook & $\begin{array}{l}\text { Yes } \\
\text { No }\end{array}$ & $\begin{array}{c}28 \\
0\end{array}$ & $\begin{array}{c}100 \\
0\end{array}$ \\
\hline $\begin{array}{l}\text { Q5: Before having the Facebook, they can } \\
\text { Communicate using other instruments in } \\
\text { preparing and finishing class assignments } \\
\text { and projects. }\end{array}$ & $\begin{array}{l}\text { Yes } \\
\text { No }\end{array}$ & $\begin{array}{c}28 \\
0\end{array}$ & $\begin{array}{c}100 \\
0\end{array}$ \\
\hline $\begin{array}{l}\text { Q6: Without the Facebook, they feel } \\
\text { difficult to prepare and communicate with } \\
\text { friends. }\end{array}$ & $\begin{array}{l}\text { Yes } \\
\text { No }\end{array}$ & $\begin{array}{c}28 \\
0\end{array}$ & $\begin{array}{c}100 \\
0\end{array}$ \\
\hline $\begin{array}{l}\text { Q7: Without the Facebook, it's difficult to } \\
\text { settle the problem in preparing the } \\
\text { assignment or projects. }\end{array}$ & $\begin{array}{l}\text { Yes } \\
\text { No }\end{array}$ & $\begin{array}{c}28 \\
0\end{array}$ & $\begin{array}{c}100 \\
0\end{array}$ \\
\hline $\begin{array}{l}\text { Q8: Feel easier with the Facebook in } \\
\text { preparing and finishing the assignments } \\
\text { and projects. }\end{array}$ & $\begin{array}{l}\text { Yes } \\
\text { No }\end{array}$ & $\begin{array}{c}28 \\
0\end{array}$ & $\begin{array}{c}100 \\
0\end{array}$ \\
\hline $\begin{array}{l}\text { Q9: Feel easier with the Facebook when } \\
\text { preparing and communicating with friends. }\end{array}$ & $\begin{array}{l}\text { Yes } \\
\text { No }\end{array}$ & $\begin{array}{c}28 \\
0 \\
\end{array}$ & $\begin{array}{c}100 \\
0\end{array}$ \\
\hline $\begin{array}{l}\text { Q10: With the Facebook, no problems in } \\
\text { preparing the assignments and } \\
\text { projects. }\end{array}$ & $\begin{array}{l}\text { Yes } \\
\text { No }\end{array}$ & $\begin{array}{c}28 \\
0\end{array}$ & $\begin{array}{c}100 \\
0\end{array}$ \\
\hline $\begin{array}{c}\text { Q11: By harnessing the Facebook, it } \\
\text { enhances Students' learning capabilities in } \\
\text { preparing the class assignments and } \\
\text { projects. }\end{array}$ & $\begin{array}{l}\text { Yes } \\
\text { No } \\
\text { Neither }\end{array}$ & $\begin{array}{c}25 \\
1 \\
2\end{array}$ & $\begin{array}{c}89 \\
4 \\
7\end{array}$ \\
\hline $\begin{array}{l}\text { Q12: By harnessing the Facebook, it } \\
\text { improves students' thinking in producing } \\
\text { quality class assignments and projects }\end{array}$ & $\begin{array}{l}\text { Yes } \\
\text { No } \\
\text { Neither }\end{array}$ & $\begin{array}{c}21 \\
5 \\
2\end{array}$ & $\begin{array}{c}75 \\
18 \\
7\end{array}$ \\
\hline
\end{tabular}

\section{REFERENCES}

[1] Facebook Statistics (2011). Retrieved Date: June 1, 2014 from $h t t p: / / w w w . f a c e b o o k . c o m /$ press/info.php?statistics.

[2] Alexa.com (2013). How popular is Facebook.com? Retrieved Date: May 26, 2014 from http://www.alexa.com.

[3] Fowler, G. A. (2012). Facebook: One billion and counting. Wall Street Journal. Retrieved Date: May 26, 2014 from http://search.proquest.com.

[4] Malaysia Social Media Statistics (2014).Malaysia Social Media Statistics. Retrieved Date: May 26, 2014 from http://blog.malaysia-asia.my/2013/09/malaysia-social-media -statistics. html.

[5] Boyd, B., \& Ellison, N. (2008).Social network sites: Definition, history, and scholarship. Journal of Computer Mediated Communication, 13 (1) (2008), pp. 210-230.

[6] Rubrico, J.G.U. (2012). Going Facebook! Action Research in Practice. Cataloguing in Publication Data: Researching Teaching in Higher Education. Our Path to Surrender by Fatimah Hashim. Pearson Malaysia Sdn Bhd, Kuala Lumpur.

[7] Pemberton, A. (2009). From friending to research - Using Facebook as a teaching tool. College \& Research Libraries 
News, 72 (1), 28-30. Retrieved Date: May 26, 2014 from http://crln.acrln.org/content/72/1/28.short.

[8] Golbeck, J. (2008). Facebook: Changing the way faculty and students interact. University of Maryland. Retrieved Date: May 26, 2014 from http://ischool.umd.edu/provost/golbeck.s html;http:

//onlinesocialnetworks.blogspot.com/2008/08/facebook-chan ging-way-faculty-and-html.

[9] Schroeder, J., \& Greenbowe, T.J. (2009). The Chemistry of Facebook: Using Social Networking to Create an Online Community for the Organic Chemistry Laboratory. Retrieved Date: 26 May 2014 from http://innovateonline.info/pdf/vol5_issue4/The_Chemistry_o f_Facebook_Using_Social_Networking to_Create an_Onlin e Community_for_the_Organic_Chemistry_Laboratory.pdf.

[10] McDonald, A. (2009). Facebook in the classroom: Integration of online and classroom debates into classes. Retrieved Date: May 26, 2014 fromhttp://akoaoteaoroa.ac.nz/ako-hub/goodpractice-publication-grants-e-book/resources/pages/faceboo $k$-classroom-integration-onlin.

[11] Van Iddekinge, C.H., Lanivich, S.E., Roth, P.L., \& Junco, E. (2013).Social Media for Selection? Validity and Adverse Impact Potential of a Facebook-Based Assessment. Journal of Management. Retrieve date: May 13, 2014 from http://jom.sagepub.com/content/early/ 2013/ 12/13/0149206 313515524.full.

[12] Brown, V. R., \& Vaughn, E. D. (2011). The writing on the (Facebook) wall: The use of social networking sites in hiring decisions. Journal of Business and Psychology, 26:219-255.

[13] Davison, H. K., Maraist, C., \&Bing M. N.(2011). Friend or foe? The promise and pitfalls of using social networking sites for HR decisions. Journal of Business and Psychology, 26: 153-159.

[14] Kluemper, D. H., Rosen, P. A., \& Mossholder, K. (2012).
Social networking websites, personality ratings, and the organizational context: More than meets the eye? Journal of Applied Social Psychology, 42: 1143-1172.

[15] Sackett, P. R., \& Ellingson, J. E. (1997). The effects of forming multi-predictor composites on group differences and adverse impact. Personnel Psychology, 50:707-721.

[16] Ployhart, R. E., \& Holtz, B. C. (2008). The diversity-validity dilemma: Strategies for reducing racio-ethnic and sex subgroup differences and adverse impact in selection. Personnel Psychology, 61: 153-172.

[17] De Bono, E. (1971). Lateral Thinking from Management. McGraw Hill Book Company, UK.

[18] Kraut, R., Pattersen, M., Lundmark,V., Kiesler, S., Mulkophadhyay, S., \& Scherlis, W. (1998). Internet paradox. A social technology that reduces social involvement, and psychological wellbeing? American Psychologist, 53, 1017-1031.

[19] Deters, F.G., \& Mehl, M.R. (2012). Does posting Facebook status updates increase or decrease loneliness? An online social networking experiment. Retrieve Date: May 26, 2014 from http://spp.sagepub.com/content/4/5/579.

[20] O'Leary, Z. (2004).The Essential Guide to Doing Research. London: Sage.

[21] McNiff, J. (1988). Action Research: Principles and Practice. London, Rutledge.

[22] Ferguson, P.B. (2011). Action research for professional development: Concise advice for new action researches Teaching Development 1. University of Waikato.

[23] Koshy, V. (2005). Action for Improving Practice: A Practical Guidelines. Retrieve Date: May 28, 2014 from http://www.actionlearning.com.au/classes/actionresearch/bo oks/book-actionresearchforimprovin gpractice.pdf. 